\title{
Cokriging Yönteminin Tarla Kapasitesi Tahmininde Kullanılabilirliğinin Belirlenmesi
}

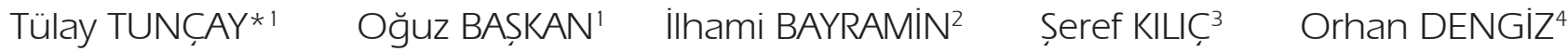

\author{
'Toprak Gübre ve Su Kaynakları Merkez Araștırma Enstitüsü, Ankara \\ ${ }^{2}$ Ankara Üniversitesi Ziraat Fakültesi, Toprak ve Bitki Besleme Bölümü, Ankara \\ ${ }^{3}$ Ardahan Üniversitesi Mühendislik Fakültesi, Çevre Mühendisliği Bölümü, Ardahan \\ ${ }^{4}$ Ondokuz Mayıs Üniversitesi Ziraat Fakültesi, Toprak ve Bitki Besleme Bölümü, Ankara
}

*Sorumlu yazar e-posta (Corresponding authore-mail): tulaytuncay@gmail.com

DOI: 10.21657/topraksu.338299

Öz

Jeoistatistik toprak biliminde son yıllarda yaygın olarak kullanılan tekniklerden biridir. Özellikle yoğun iș gücü ve emek gerektiren analiz sonuçlarının konumsal dağılımlarının belirlemek amacıyla eș kestirim (cokriging) tekniği yaygıın olarak kullanılmaktadır. Bu çalıșmada TiGEM'e bağlı Altınova Tarım İșletmesi arazisinde $32 \mathrm{~km}^{2}$ lik (8 parsel) bir alanda yürütülmüștür. Toprak örneklemesi $500 \mathrm{~m}$ aralıklarla grid yöntemi ile toplam 135 adet yüzey örneklemesi $(0-20 \mathrm{~cm})$ yapılmıș ve alınan örneklerinin bünyeleri belirlenmiștir. Çalıșmada aynı zamanda co-kriging tekniğinin önemli ölçüde zaman ve ișgücü gerektiren tarla kapasitesi değerinin tahmin etmedeki etkinliğinin belirlenmesi amacıyla azaltılmıș toprak örneklemesi ile tarla kapasitesi değerleri belirlenmiștir. Korelasyon analizi sonuçlarına göre tarla kapasitesi ile en yüksek ilișki gösteren kil değeri (R: 0,68) analiz için yardımcı değișken olarak seçilmiștir. Cokriging tekniği tarla kapasitesi değerinin konumsal yapısını tahmin etme etkinliği ortalama mutlak hata $(\mathrm{OMH})$ ve hata kareler ortalaması (HKO) değerleri dikkate alınarak azaltılan oranlarda tarla kapasitesi değerleri ile test edilmiștir. Sonuçlar cokriging tekniğinin toprak özelliklerinin tahmin edilmesinde önemli avantaj sağladığını göstermiștir. Cokriging tekniği 63 TK değerleri için bile düșük MAE ve MSE değerleri konumsal yapının doğru bir șekilde haritalanmasını sağlamıștır. Araștırma sonucu yüksek korelasyon katsayısının konumsal yapıyı doğru yansıtmada tek bașına yeterli olmadığını, bununla birlikte konumsal yapıyı doğru yansıtan yardımcı değișkene gereksinim duyduğunu göstermiștir.

Anahtar Kelimeler: Cokriging, jeoistatistik, kriging, yarıvariogram

\section{Determination of the Applicability of the Cokriging Method in Estimating Field Capacitiy}

\begin{abstract}
In recent years, geostatistic has become a commonly used method in soil science. The co-kriging technique is widely utilized in determining the spatial distribution of particularly labor- and effortintensive analysis results. This study was conducted over a $32-\mathrm{km}^{2}$ area (eight plots) within the Altınova Agricultural Enterprise, a subsidiary of the General Directorate of Agricultural Enterprises (TiGEM). A total of 135 soil samples $(0-20 \mathrm{~cm}$ ) were collected on a $500 \mathrm{~m}$-spaced grid, and it was determined to soil texture in all soil samples. Additionally, field capacity (FC) values were determined through reduced sampling with an aim to assess the effectiveness of the co-kriging method in the estimation of FC values that require significant amounts of time and labor. On the basis of the results of correlation analysis, the clay value (R: 0.68$)$ showing the highest correlation with FC was selected as a sub-variable. The effectiveness of the co-kriging technique in estimating the spatial structure of the FC value was tested with reduced proportions of FC values by taking the Mean Absolute Error (MAE) and Mean Squared
\end{abstract}


Error (MSE) values into account. The results obtained highlighted the significant advantages of the co-kriging method in the estimation of soil properties. The co-kriging technique enabled accurate mapping of the spatial structure even for 63 FC values with Iow MAE and MSE values. The current study has shown that a high correlation coefficient is insufficient in accurate representation of the spatial structure by itself, but it requires an auxiliary variable.

Anahtar Kelimeler: Cokriging, geostatistic, kriging, semivariogram

\section{Gíriș}

Jeoistatik metotlar, araștırma alanı içerisinde incelenen toprak özelliğinin konumsal değișikliğinin belirlenmesi ve bu özelliğin örneklenmeyen bir noktada en az hata ile tahmin edilmesine olanak sağlamaktadır (Öztaș, 1995; Bașkan, 2004). Jeoistatistik ilk defa Güney Afrika'da madencilik araștırmalarında D.G. Krige tarafından (1951) kullanılmıș, temel prensipleri ise ilk olarak Matheron (1963) tarafindan belirlenmiștir.

Konumsal Özellikler yarıvariogramlarla ifade edilmektedir. Uygun konumsal yapının tahmin edilmesi ve haritalanması faktöriyel kriging veya kriging analizleri olarak bilinen kriging varyasyonlarının kullanılması ile yapılmaktadır (Matheron, 1982; Goovaerts, 1992).

Örnekler arasındaki konumsal bağımlılık mesafe boyutundan bașka yöne göre de olușabilir. Incelen özellikler için belirlenen yarıvariogram değerlerinin yönlere göre değișiklik göstermesi yönsel bağımlılığın (anisotroptik) bir göstergesidir. Yönsel bağımlıı̆̆ın oluștuğu durumlarda, varyasyonun maksimum ve minimum olduğu yönler dikkate alınarak hesaplanan bir katsayının yarıvariogramın eğim bileșimine ilave edilmesi gerekmektedir (Webster ve Oliver, 1990).

Hassas tarımın etkinliğinin toprak özelliklerinin doğru ve etkili șekilde haritalanmasına bağlı olduğu bilinmektedir. Toprak özelliklerinin haritalanmasında toprak örnekleme sayısı, örnekleme noktaları arasındaki mesafe ve interpolasyon ișlemlerinin seçimi gibi birçok faktör etkili olmaktadır. Kravchenko (2003), bu amaçla yaptığı çalıșmasında, farkı örnekleme yoğunluğunda grid toprak örneklemesini, iki interpolasyon ișleminin performansı üzerine verilerin uzaysal korelasyon kuvvetinin ve veri değișkenliğinin etkisini değerlendirmesini amaçlamıștır. Sonuç olarak, toprak örneklerinin \%12-67 arasında değișen varyasyon katsayısıyla grid noktaları arasında 30 m'lik mesafede düzenli grid yöntemi kullanılarak 20 ha'lık bir alanda örneklendiği, simüle edilen uzaysal yapıların kuvvetinin zayıf külçe etkisi/ eșik değeri oranında $(0,6)$ güçlü etkisi/eșik değeri oranına $(0,1)$ doğru sıralandığı ve sonuçların değișim katsayısına bakılmaksızın güçlü uzaysal yapıya sahip toprak özelliklerinin zayıf uzaysal ilișkiye sahip toprak özelliklerinden daha doğru olarak haritalandığı belirtilmiștir.

Tarımsal üretimde geleceğe yönelik amenajman uygulamalarına karar verebilmek için öncelikle toprak özelliklerinin uzaysal değișkenliğinin belirlenmesi önem tașımaktadır (Corwin ve Lesch, 2005; Corwin vd., 2006). Bitkisel üretim ve verimlilik için bitkiye yarayıșlı su, infilitrasyon, toprak bünyesi ve strüktürü, toprak derinliği, sınırlayıcı toprak katmanları, organik madde gibi kimyasal bileșenlerle birlikte iklim ve topoğrafya gibi arazi özellikleri de önemli oranda etkili olmaktadır (Black, 1968; Tanji, 1996; Webster, 1985; Hillel, 1991; Sylla vd., 1995; Jordan vd., 2003). Bununla birlikte bazı araștırmacılar kriging yöntemi yerine cokriging (eș kestirim) yöntemi ile yardımcı değișken kullanarak tahmin yapma yoluna gitmișlerdir (Chang, 2002; Pawlowksy vd., 1995).

Bu çalıșma ile yoğun iș gücü ve emek gerektiren analiz sonuçlarının konumsal dağıımlarının belirlemek amacıyla eș kestirim (cokriging) tekniğinin kullanılabilirliğinin belirlenmesi amaçlanmıștır.

\section{MATERYAL VE YÖNTEM}

\section{Araștırma Alanının Coğrafik Konumu ve İklim Özellikleri}

Bu çalıșma Tarım ișletmeleri Genel Müdürlüğü'ne ait Altınova Tarım İșletmesi'nde yürütülmüștür. ịç Anadolu Bölgesinin 421239/3535249 m Doğu ve 488389/4272469 m Kuzey enlemleri arasında yer alan ortalama 915 m rakıma sahip Altınova TiGEM, Konya iline bağı Kadınhanı ilçesinin 60 km kuzeyinde, Ankara'ya 189 km ve Konya iline 126 km uzaklıktadır (Șekil 


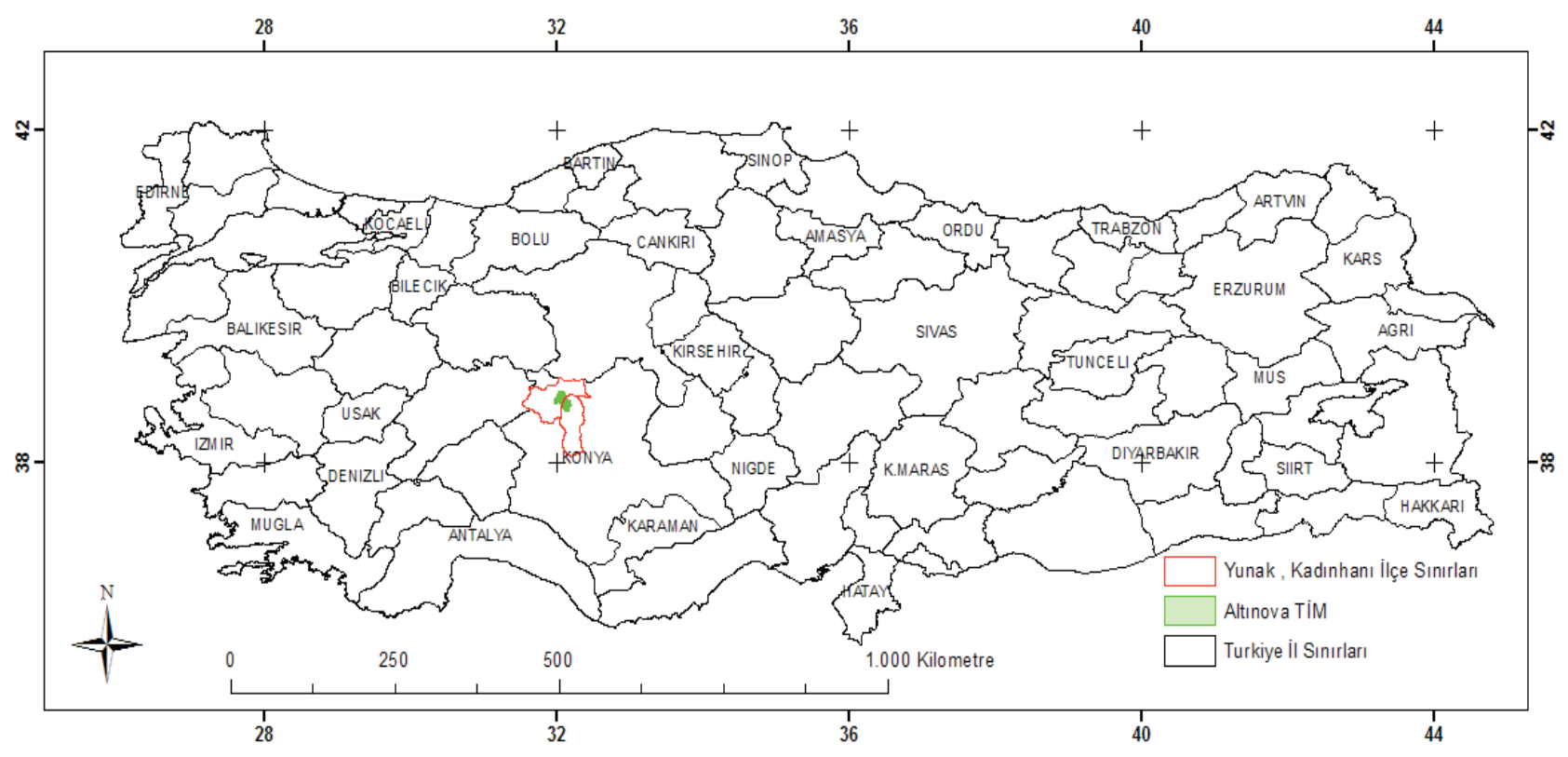

Sekil 1. Calıșma alanının yerbulduru haritası

Figure 1. Site location map of the study area

1). İșletme 29608,6 ha'ık arazi varlığına sahiptir. Kültür altındaki alanlarda buğday, arpa, tritikale, yonca, mısır gibi ürünler yetiștirilmektedir. Bunlar arasında buğday yaklașık 114.000 da'ık alana ekilerek ișletme alanının önemli kısmını olușturmaktadır. Bunu 16.000 da'lık ekimiyle arpa ve yaklașık 350 da ile tritikale takip etmektedir (http://www.tigem.gov.tr/). İșletmede nadas ekim sistemi uygulanmaktadır.

Altınova Tarım ișletmesi meteorolojik verilerinden elde edilen toprak - su bütçesi diyagramına göre; yıllık ortalama toprak sıcaklığının $8{ }^{\circ} \mathrm{C}^{\prime}$ den fazla, fakat $15{ }^{\circ} \mathrm{C}^{\prime}$ den daha az ve ortalama yaz sıcaklığı (Haziran, Temmuz, Ağustos) ile ortalama kıș sıcaklığı (Aralık, Ocak, Șubat) arasındaki fark $5{ }^{\circ} \mathrm{C}$ 'den daha fazla olması nedeniyle araștırma alanı toprakları sıcaklık rejimi Mesic'tir. Ayrıca toprağın ardıșık 90 gün den fazla (5 ay ) toprağın kuru kalması nedeniyle araștırma alanı Aridik nem rejimine dahil edilmiștir.

\section{Toprak örneklemesi ve analiz}

Bu çalıșmada TiGEM'e bağlı Altınova Tarım İșletmesi arazisinde $32 \mathrm{~km}^{2 \prime}$ lik toplam olarak 8 parselde (P53, 54, 55, 56, 59, 60, 61 ve 62 nolu, yürütülmüștür (Șekil 2). Çalıșma alanında 500 m aralıklarla grid yöntemi ile toplam 135 adet yüzey toprak örneklemesi $(0-20 \mathrm{~cm})$ yapılmıș ve alınan örneklerin bünyeleri (Bouyoucos, 1951) belirlenmiștir. Aynı zamanda alınan örneklerin 63 tanesinde tarla kapasitesi analizi (Anonymous, 1992) yapılmıștır.

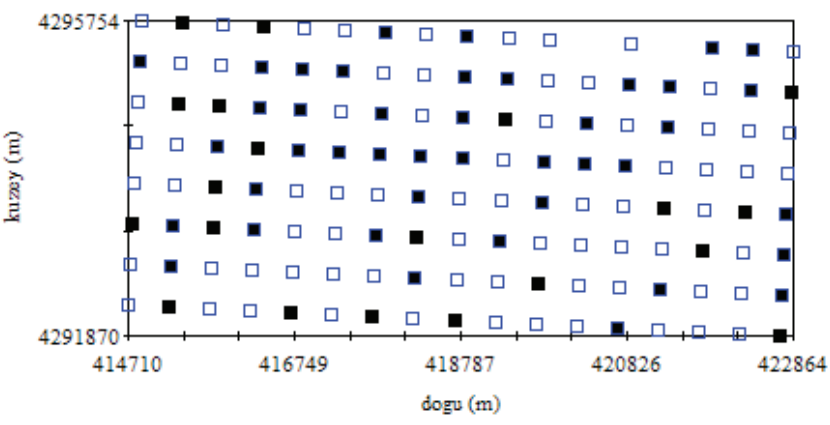

Șekil 2. Örnekleme deseni

Figure 2. Sampling design

\section{Tanımlayıcı istatistikler}

Alınan toprak örneklerinde kil içeriği ve tarla kapasitesi verilerine ait minimum, maksimum, ortalama, standart hata, değișim katsayısı ve çarpıkıı katsayısı gibi tanımlayıcı istatistikler yapılmıștır. Kil içeriği ve tarla kapasitesi değerlerinin normal dağııma uygunlukları KolmogorovSmirnov (K-S) testi ile kontrol edilmiștir.

\section{Jeoistatistiksel analiz}

Çalıșma alanında kil içeriği ve tarla kapasitesi değerleri için elde edilen veriler jeoistatistik yöntem ile değerlendirilerek deneysel yarıvariogramlar olușturulup, konumsal bağımlılık dereceleri belirlenmiștir. Her bir değișken (kil içeriği ve tarla kapasitesi) için en uygun yarıvariogram modelleri, farklı modellerin farklı araștırma stratejileri kullanılarak test edilmesine olanak sağlayan (Goovaerts, 1997) çapraz doğrulama analizi ile belirlenmiștir (Yates ve Warrick, 1987). 
Yarıvariogramlar belli bir $x$ mesafesi ile birbirlerinden ayrılan örnek çiftleri arasındaki varyansın mesafeyle olan ilișkisini gösterirler. Diğer bir ifade ile örnekleme çiftleri arasındaki mesafenin bir fonksiyonu olarak uzaysal bağımlılı̆ı tanımlar ve matematiksel olarak așağıdaki Eșitlik 1 ile ifade edilirler (Journel ve Huijbregts 1978).

Her bir h uzaklığı için deneysel variogram

$y^{*}(h)=\frac{1}{2 N(h)} \sum_{i=1}^{N(h)}\left[Z\left(x_{i}\right)-Z\left(x_{i}+h\right)\right]^{2}$

ile hesaplanır. Eșitlikte $N(h)$; h uzaklığına karșılık gelen örnek çifti sayısını, Z $\left(x_{i}\right)$ incelenen özelliğin “ i " noktasındaki ölçüm değerini, $Z\left(x_{i}+h\right)$ incelenen özelliğin “ i $+h$ " noktasındaki ölçüm değerini göstermektedir.

Her model için ortalama mutlak hata $(\mathrm{OMH})$ ve hata kareler ortalaması (HKO) değerleri hesaplanmıștır (Eșitlik 2 ve 3). Yarıvariogram modellerinin olușturulmasında yönlere göre olası bağımlılık (geometrik anizotropi) test edilmiș, bu amaçla farklı dört yönde $\left(0^{\circ}, 45^{\circ}, 90^{\circ}\right.$ ve $\left.135^{\circ}\right)$ yarıvariogramlar olușturulmuștur.

$\mathrm{OMH}=\frac{1}{n} \sum_{i=1}^{n}\left[Z\left(x_{g}\right)-Z *\left(x_{t}\right)\right]$

$\mathrm{HKO}=\frac{1}{n} \sum_{i=1}^{n}\left[Z\left(x_{g}\right)-Z^{*}\left(x_{t}\right)\right]^{2}$

\section{g: gözlemlenen değer}

t: tahmin edilen değer

\section{Kestirim (Kriging) ve Eș Kestirim (Cokriging)}

Çalıșma alanında doğrusal interpolasyon tekniği olan, örnekleme yapılmayan alanların tahmininde kullanılan kriging yöntemi ile kil ve tarla kapasitesi değerleri 100 × 100 m aralıklarla olușturularak 3159 noktada kestirim yapılmıștır. Kestirim ișleminde en az 6 en fazla 9 komșuluk değeri kullanılmıștır (GS+7.0). Yapılan kestirim ișlemi variogramın yapısal özelliklerini ve örneklenmiș noktaları kullanarak örnek alınmamıș noktalardaki değișkeni tahmin etmeyi sağlayan bir interpolasyon tekniğidir (Tragmar et al. 1985) ve așağıdaki șekilde ifade edilmektedir (Eșitlik 4).

$Z_{0}=\sum_{i=1}^{N} Z_{i} * W_{i}$
$Z_{0} \quad$ : Tahmin edilen değer

$Z_{i} \quad$ : Ölçülen değer

$W_{i} \quad$ : Ağırlığı ifade etmektedir.

Ağırlık $\left(W_{i}\right)$;

$\mathrm{Wi}=r^{-1} \times \mathrm{C}$

Wi : Ağılık vektörü

$r \quad$ : Variogram matrisi

C : Tahmin edilecek nokta ile tahminde kullanılacak örnekler arasındaki uzaklığa ilișkin variogramları içeren vektördür.

Çalıșma alanında tarla kapasitesi değerlerinin kil içeriğini yardımcı değișken olarak kullanarak alansal dağıım haritasını olușturmak amacıyla 100×100 m aralıklarla gridler olușturulmuș, cokriging yöntemi kullanılarak toplam 3159 noktada kestirimler yapılımıștır (Eșitlik 5).

$Z^{*}=\sum_{i=1}^{n} \lambda_{i} Z_{i}+\sum_{j=1}^{m} \lambda_{j} y_{i}$

$\lambda_{i} \lambda_{i}$, sırası ile $Z$ ve $Y$ değișkenlerine ait ağılıkları, $m$ ve n'ler ise sırası ile $Z$ ve $Y$ değișkenlerine ait kestirimde kullanılan veri sayısını ifade eder.

Kriging ișleminde atanan ağırlıklar așağıdaki sınırlandırmalara dikkate alarak hata varyansını minimize ederek kestirim yapmaktadır

$\sum_{i=1}^{n} \lambda_{i}=1 \mathrm{ve} \sum_{i=1}^{n} \lambda_{j}=0$

Eș kestirim (cokriging) kestirimlerde birincil ve ikincil değișkenler arasındaki covaryansdan faydalanmaktadır. Birincil değișkenin yeteri kadar örneklenmediği ve ikincil değișkenin daha iyi örneklendiği, birincil ve ikincil değișkenler arasındaki kovaryansın iyi modellenebildiği durumda kestirim kalitesini arttırıması için cokriging yöntemi kullanılmaktadır (Gruitjer et al. 1997; Chang, 2002)

\section{BULGULAR VE TARTISTMA}

Çalıșma alanındaki kil içeriği ve tarla kapasitesi değerlerinin tanımlayıcı istatistik verileri Çizelge I'de sunulmuștur.

Çizelge 1'den de görüldüğü gibi kil değerleri tarla kapasitesi değerlerine göre daha yüksek 
Çizelge 1. Kil (\%) ve tarla kapasitesi değerlerinin tanımlayıcı istatistikleri

Table 1. Descriptive statistic of (\%) clay and field capacity

\begin{tabular}{ccccccccc}
\hline Değișken & $N$ & Ort. & Std. sapma & Minimum & Maksimum & Çarpıklık & Basıklık & Değișim Katsayısı \\
\hline Kil (\%) & 135 & 33,21 & 6,82 & 18,53 & 55,55 & 0,61 & 1,39 & 20,55 \\
TK & 63 & 33,80 & 4,82 & 22,51 & 48,44 & 0,67 & 1,16 & 14,46 \\
\hline
\end{tabular}

değișim katsayısına ve standart sapmaya sahiptir. Her iki değișkenin basıklık değerinin pozitif olması normalden daha dik bir dağılıma ve çarpıklık katsayılarının da O'dan büyük olması nedeniyle + yöne eğimli ve sağa çarpık bir dağılımın göstergesidir. Verilerdeki çarpıklığı gidermek amacıyla karekök dönüșümü uygulanmıș ve histogramlar Șekil 3’de verilmiștir.
Kil ve tarla kapasitesi için olușturulan yarıvariogram modellerinin uygunluğu ortalama mutlak hata (OMH) ve hata kareler ortalaması (HKO) değerleri hesaplanarak kontrol edilmiștir. Küçük OMH ve HKO değerleriyle tüm modellerin konumsal yapıyı doğru tahmin ettiğine karar verilmiștir. Cokriging yöntemi ile tarla kapasitesinin kil yardımcı değișkeni ile tahmin edilmesinde
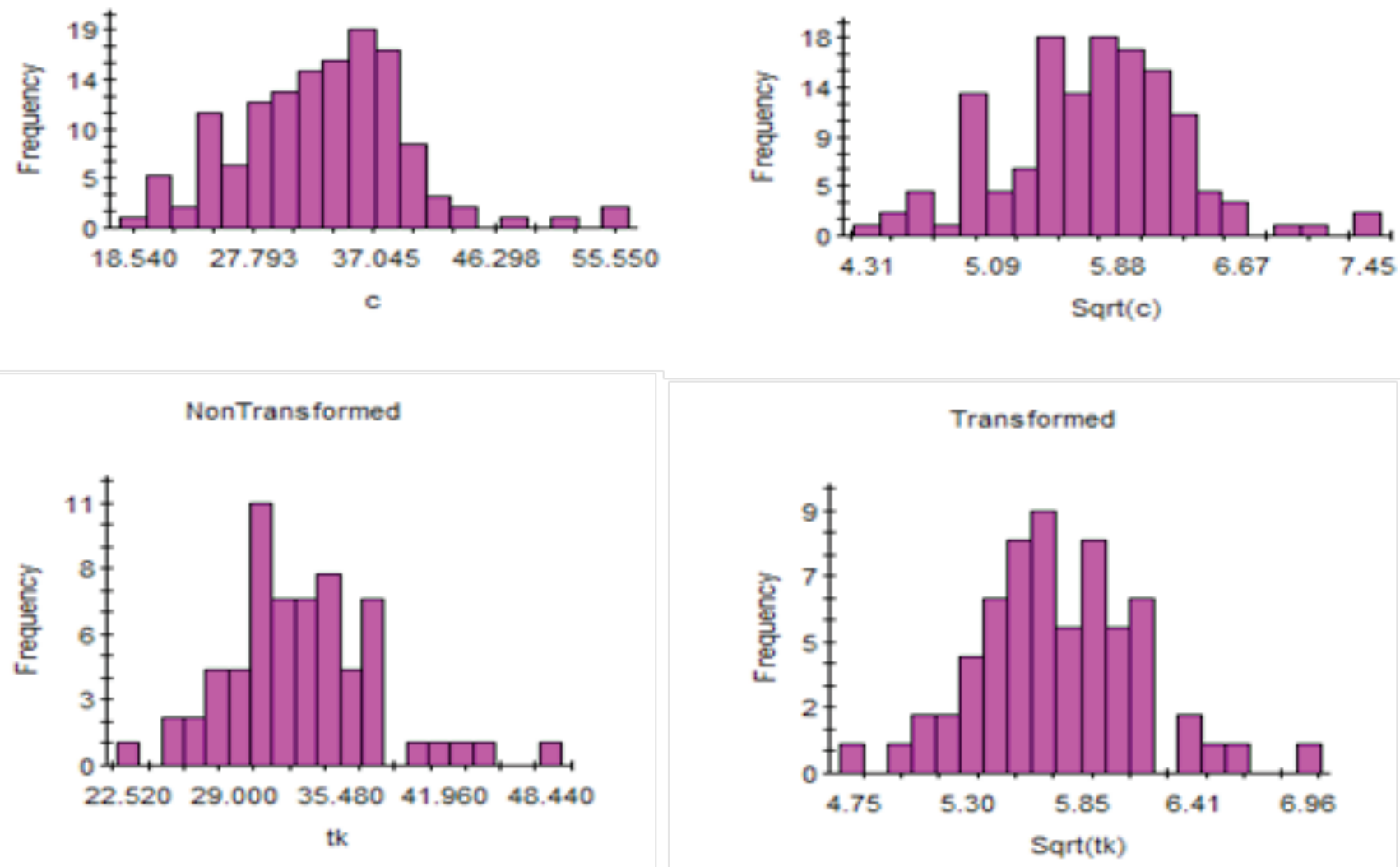

Șekil 3. Kil içeriğine (a) ve tarla kapasitesi (b) değerlerine ve cokriging'e ait variogramlar

Figure 3. Variograms of clay content (a), field capacity values and cokriging

Çizelge 2. Kil ve tarla kapasitesi değerlerinin yarıvariogram modelleri ve çapraz doğrulama analiz sonuçları

Table 2. Semi variogram models and cross validation results of clay and field capacity values

\begin{tabular}{lccccccc}
\hline & Model & CO & CO+C & A & C/CO+C & OMH & HKO \\
\hline Kil & Küresel & 0,15320 & 0,35140 & 3180 & 0,5640 & 4,15 & 9,15 \\
Tarla Kap. & Küresel & 0,00460 & 0,16620 & 1450 & 0,972 & 3,18 & 6,55 \\
Kil x TK & Küresel & 0,00180 & 0.15060 & 1101 & 0,988 & 2,13 & 5,79 \\
\hline
\end{tabular}

CO: kontrolsüz etki varyansı; CO+C: tepe varyansı; A: etki aralığı (m); MAE: ortalama mutlak hata; MSE: hata kareler ortalaması 
en düșük ortalama mutlak hata ve hata kareler ortalaması elde edilmiștir. Bununla birlikte tarla kapasitesi değerlerinin ortalaması $(33,38)$ ile cokriging eș kestirim ile elde edilen verilerin ortalamasının $(33,20)$ birbirine yakın cıkmıs olması yöntemin analizi uzun ve masraflı olan analizlerde kullanılabilirliğinin bir göstergesidir Șekil 4 ve Șekil 5 (Pawlowsky- Glahn \& Olea. 2004).

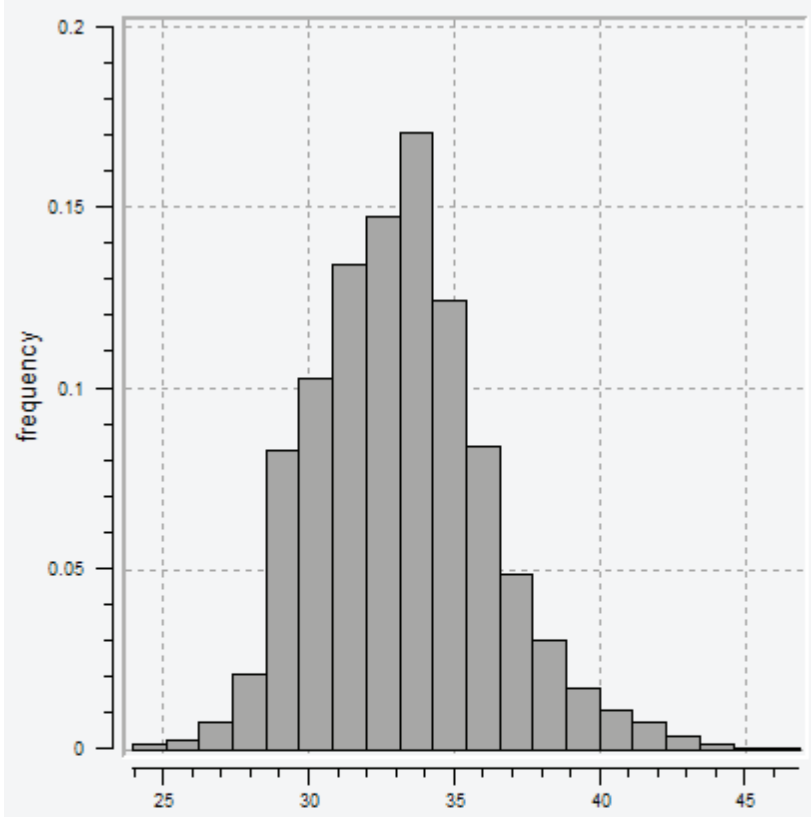

Șekil 4. Cokriging sonucu elde edilen verilerin histogramı

Figure 4. Histogram of datas obtained from cokriging results

Tarla kapasitesi değerlerina ait cokriging haritasında görüldüğü gibi çalıșma alanının kuzeybatısında ve güneydoğusuna yakın yerlerde kil içeriğinin yüksek olmasına bağlı eș kestirim yönteminde de aynı yerlerde tarla kapasitesi değerleri yüksek çıkmıștır.

\section{SONUC̣LAR}

Bu çalıșmada 500 m aralıkla 135 noktadan alınan toprak örneklerinde kil (\%) ve tarla kapasitesi değerleri analiz edilerek belirlenmiștir. Elde edilen analiz sonuçları kullanılarak önce her bir değișken için tanımsal istatistikler yapıımıș, daha sonra uzaysal değișkenliği belirlemek amacıyla uygun teorik variogramlar belirlenmiștir. Seçilen variogram modellerinin, alanın uzaysal yapısının doğru olarak yansıtıp yansıtmadığı çapraz doğrulama analizleri ile kontrol edilmiștir. Değișkenlerde yöne bağlı değișim göstermemiștir. Kil ve tarla kapasitesi arasındaki korelasyon katsayısı 0,68 olarak hesaplanmıștır. Calıșma alanında tarla kapasitesi değerlerinin kil yardımcı değișkeni ile cokriging yöntemi ile tahmin edilmiștir. Cokriging yönteminin çapraz doğrulama sonuçlarına göre, ortalama mutlak hata ve hata kareler ortalaması daha düșük çıkmıștır. Uzun ve yoğun iș gücü gerektiren analizlerde cokriging yöntemi ile tahmin edilebilirliğini göstermiștir.

Kriging yönteminde sadece birincil değișkene ait veriler kullanılarak kestirim yapılmaktadır. Ancak eș kestirim yönteminde ikincil veriler de kullanılarak birincil verilerin olmadığı konumlarda ikincil veriler kullanılarak kestirim kalitesi arttırmak mümkündür.

\section{Teșekkür}

Bu çalıșma 1100729 kodlu TUBITAK TOVAG tarafından desteklenmiștir. Desteklerinden dolayı teșekkür ederiz.
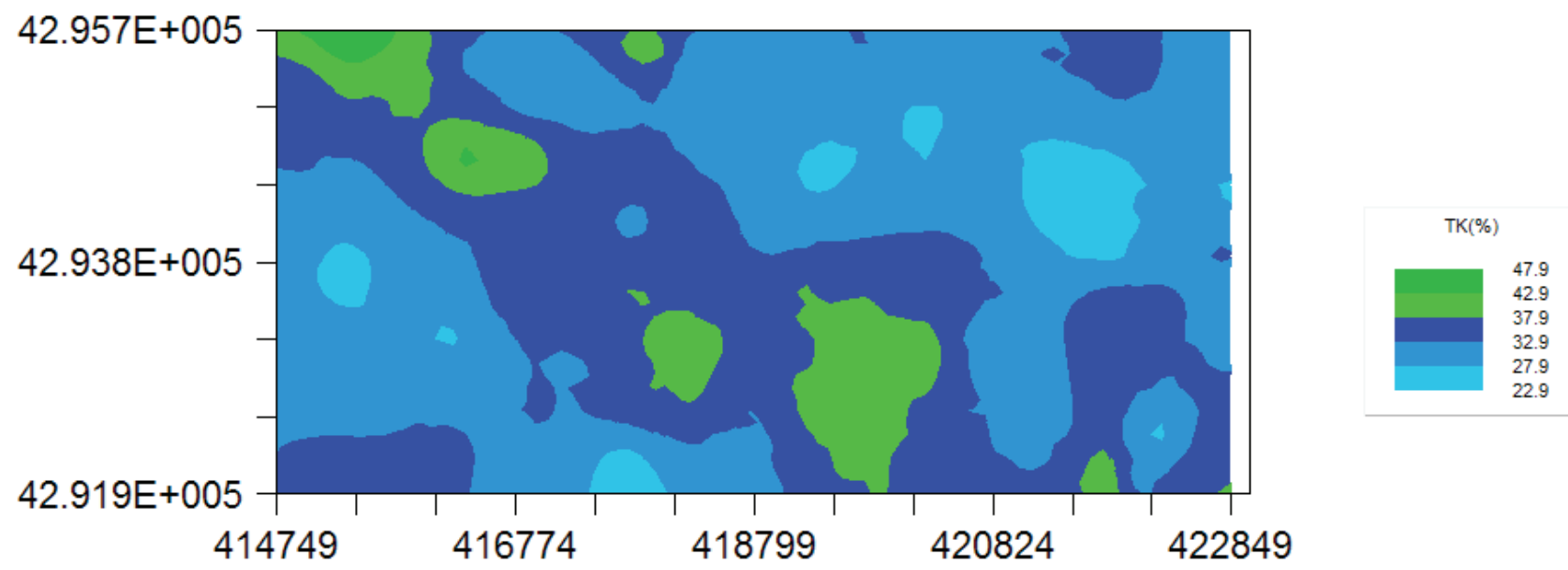

Șekil 5. Tarla kapasitesine ait cokriging haritası

Figure 5. Cokriging map of field capacity 


\section{KAYNAKLAR}

Anonymous (1992). Soil Survey Methods Manual. USDA. Soil Survey Investigations Report No:42.

Bașkan O (2004). “Gölbașı Yöresi Topraklarının Mühendislik- Fiziksel Özellik İlișkilerinde Jeoistatistik Uygulaması", Ankara Üniversitesi Ziraat Fakültesi Toprak Bölümü, Yayınlanmamıș Doktora Tezi, 176 sayfa, Ankara.

Black C A (1968). "Soil-Plant Relationships", 2nd Edition, John Wiley \& Sons, Inc., NewYork, NY.

Bouyouces G J (1951). A Recalibration of the Hydrometer Method for Making Mechanical Analysis of Soils. Agron. J., 43, p 434-438.

Burgess T M, Webster R (1980). Optimal Interpolation and Isarithmic Mapping of Soil Properties. I. The Semivariogram and Punctual Kriging. J. Soil Sci. 31:315-331.

Chang KL (2002). Optimal estimation of the granulometric composition of soils. Soil Science, 167, 135-146.

Corwin D L, Lesch S M, Oster J D, Kafka S R (2006). "Monitoring Management- Induced Spatio-Temporal Changes in Soil Quality through Soil Sampling Directed by Apparent Electrical Conductivity", Geoderma, 131, Issues 3-4, pp: 369-387.

Corwin D L, Lesch S M (2005). “Characterizing Soil Spatial Variability with Apparent Soil Electrical Conductivity I. Survey Protocols", Computers and Electronics in Agriculture, 46, pp: 103-133.

Goovaerts P., (1992). “Factorial Kriging Analysis: A Useful Tool for Exploring The Structure of Multivariate Spatial Soil Information", Journal of Soil Science, 43, pp: 597-619.

Goovaerts, P., 1997. Geostatistics in soil science: state-ofthe-art and perspectives. Geoderma. 89:1-45.

de Gruitjer J J, Walvoort D J J, van Gaans P F M (1997). Continuous soil maps- a fuzzy set approach to bridge the gap between aggregation levels of process and distribution models, Geoderma, 77, 169-195.

Hillel D (1991). “Research in Soil Physics: A Review”, Soil Sci., 151, pp: 30-34.

Jordan M M, Navarro-Pedreno J, Garcia-Sanchez E, Mateu J, Juan P (2003). "Spatial Dynamics of Soil Salinity under Arid and Semi-arid Conditions: Geological and Environmental Implications", Environ. Geol., 45(4), pp: 448-456.
Journel A G, Huijbregts C H J (1978). Mining Geostatistics. Academic Pres. London.

Kravchenko A N (2003). "Influence of Spatial Structure on Accuracy of Interpolation Methods", Soil Sci. Soc. Am. J., 67, pp:1564-1571.

Krige D G (1951). "A Statistical Approach to Some Mine Valuationsand Allied Problems at Witwatersrand", M.Sc. thesis, University of Witwatersrand.

Lark R M, Bishop T F A. Cokriging particle size fractions of the soil. European Journal of Soil Science, doi: 10.1111/j.1365-2389.2006.00866.x.

Matheron G (1963). "Principles of Geoistatistics", Eron. Geol., 58, pp:1246-1266.

Matheron G (1982). "Pour Une Analyse Krigeante de Donnees Regionalisees, Centre de Geostatistique, Ecole des Mines de Paris, Report N- 732, Fontainebleau.

Öztas T (1995). “ Jeoistatistigin Toprak Bilimindeki Önemi ve Uygulanıșı", IIIhan Akalan Toprak ve Çevre Sempozyumu, Cilt I. Sayfa: 271-280, Ankara.

Pawlowksy V, Ole R, Davis J C (1995). Estimation of regional-ized comparison of three methods. Mathematical Geology, 27, 105-127.

Pawlowsky- Glahn, V, Olea R A (2004). Geostatistics Analysis of Compositional Data. Oxford University Press, New York.

Sylla M, Stein A, van Breemen N, Fresco L O (1995). "Spatial Variability of Soil ,Salinity at Different Scales in the Mangrove Rice Agro-ecosystem in West Africa", Agric Ecosyst. Environ., 54, pp: 1-15.

Tanji K K (ed.). (1996). “Agricultural Salinity Assessment and Management", ASCE, New York, NY

Tragmar B B, Yost R J, Uehara G (1985). Application of Geostatistics to Spatial Studies of Soil Properties, Advance in Agronomy, 38, 65-91.

Webster R (1 985). "Quantitative Spatial Analysis of Soil in the Field", Adv. Soil Sci., 3, pp: 1-70.

Webster R, Oliver M A (1990). "Statistical Methods in Soil and Land Resource Survey", Oxford University Pres, Oxford.

Yates S R, Warrick AW (1987). Estimating soil water content using cokriging. SSSAJ. 51:23-30. 